Cakrawala Dini: Jurnal Pendidikan Anak Usia Dini | p-ISSN 2087-I317 | e-ISSN 2621-8321

Vol. I2. No.I Mei ZQZI| Hal I-6

\title{
ISSUES AND CHALLENGES IN THE ASSESSMENT OF CHILDREN IN NURSERY
}

\author{
Norazly Nordin ${ }^{1}$, Muhammad Safar Abdurahman $^{2}$, Afina Nazira Afnizul ${ }^{3}$ \\ ${ }^{1}$ PICOMS International University College, Kuala Lumpur, Malaysia, \\ ${ }^{2,3}$ University of Selangor, Selangor, Malaysia,
}

\begin{abstract}
Assessment is a systematic and on-going process of attaining information about a child's development and learning progress. Assessment is often conducted by professional educators in collaboration with parents through regular observation and several standardized tests. Assessment is very significant to identify the strengths and weaknesses to support and provided interventions needed by the child to elevate their development. Every nursery institution must implement the assessment process to ensure a well-balanced development of the children. Accordingly, a qualitative study using the interview method was conducted in a private nursery in the state of Selangor involving a nursery owner, a supervisor, and four educators to identify issues and challenges faced in implementing the assessment. The results found that many aspects including the educator's competence, cooperation from parents, time constraint and record management are the main issues and challenges encountered in executing the assessment. The informants also suggested that continuous training and effort for educators and advocacy should be intesified to educate the community. It is also underlined that there is a need for the integration of Information and Communication Technology (ICT) to ensure the efficiency of the assessment process.
\end{abstract}

Keyword: Assessment, development, nursery, issues on assessment

\begin{abstract}
Abstrak: Asesmen merupakan proses yang sistematik dan berkelanjutan dalam mendapatkan informasi tentang perkembangan dan kemajuan pembelajaran seorang anak. Asesmen biasanya dilakukan oleh seorang pendidik professional bekerjasama dengan orang tua melalui observasi yang dilakukan secara teraturdan beberapa tes standar. Asesmen sangat penting untuk mengidentifikasi kelebihan dan kekurangan untuk mendukung dan memberikan interfensi yang dibutuhkan oleh anak untuk meningkatkan perkembangannya. Setiap institusi Taman Kanak-kanak harus mengimplementasikan proses asesmen untuk memastikan perkembangan anak yang seimbang. Oleh karena itu, dilakukan penelitian kualitatif ini dengan menggunakan metode wawancara di sebuah TK swasta di Selangor yang melibatkan seorang pemilik TK, seorang pengawas dan 4 orang guru untuk mengidentifikasi berbagai masalah dan tantangan yang dihadapi dalam mengimplementasikan asesmen. Hasil penelitian menunjukan bahwa banyak aspek diantaranya kompetisi guru, kerjasama orang tua, kendala waktu dan managemen pengumpulan informasi merupakan masalah utama yang dihadapi dalam melakukan asesmen. Informan juga menyarankan bahwa pelatihan yang berkelanjutan dan kerja keras para guru dan penyuluhan perlu ditingkatkan untuk memahamkan masyarakat. Hal penting lain yaitu perlunya integrasi ICT untuk memastikan efisiensi proses asesmen.
\end{abstract}

Kata kunci: Asesmen, perkembangan anak, taman kanak-kanak, masalah dalam asesmen

\footnotetext{
I PICDMS International University College, Email: narazly国picams.edu.my

${ }^{2}$ University of Selangor, Email: m.safarD7国unisel.edu.my

${ }^{3}$ University of Selangar, Email: afinanazira国unisel.edu.my
} 


\section{INTRODUCTION}

Assessment of a child development is an on-going process that needs to be done to recognize the needs of each child, trace their growth, developmental stage and to also identify the strengths and difficulties faced by children. In addition, through the assessment, follow-up assistance to aid the children's development can also be identified and implemented (Permata, 2013). Accordingly, a developmental assessment shall be conducted continuously in accordance with the provisions underlined in the Education Act 1996 and further outlined in the Education (Preschool) Regulations 1997:

5 (1) Every nursery shall make continuous assessments of the development of its pupils in the cognitive, affective and psychomotor domains.

According to Nur., et. all (2016), children's performance should be tracked regularly to ensure that their progress complements the milestones set for each stage of development. Norsyafinaz and Faridah (2018) also found that academic qualifications and the duration of service of the educators influence factors in implementing assessment at an early stage of childhood. The study revealed that educators with more than three years of service plan, implement and assess the children during teaching and learning process. This situation initiates the study which to analyse the issues and challenges educators face in conducting an assessment of child development.

Having identified the issues and challenges, the relevant parties in the early childhood education sector such as the government, school management, educators and parents can devise imperative plans to advance and strengthen the process of assessing children in nurserys. Therefore, it is hoped that this study could assist the parties involved to ensure that children's assessment in the nursery can be carried out effectively.

\section{RESEARCH QUESTIONS}

This study was conducted to answer the following questions:

1. What are the common issues during the children's assessment process in nursery?

2. What are the challenges faced by the institutions in the process of assessing the child development?

3. What are the suggestions to overcome these challenges?

\section{METHODOLOGY}

This study is a qualitative study that operates a focus group discussion (FGD) approach. According to Nyumba, Wilson, Derrick \& Mukherjee (2018), FGD is often used as a qualitative research approach for the in-depth understanding of social science issues.

\section{INFORMANTS}

According to Merriam (2009), the number of informants suitable for an FGD session is between six to ten people and has experience and expertise in the same field. Therefore, this study has selected six informants: a nursery owner, a nursery supervisor, and four nursery educators.

The subjects' academic qualification were diploma, bachelor, master, and PERMATA certification. Permata Care certification (KAP) is a three-month course certified by Department of Social Welfare Malaysia (JKM) which is awarded for educators who have completed the course. This course aims to fulfil the employment requirements as outlined in the Child Care Centers Act 1984 (Act 308) and the Child Care Centers Regulations 2012 (TASKA Regulations) to all prospective employers, managers, supervisors and Nursery teachers. This comprehensive course will train and guide teachers on how to care for, nurture and educate infants and children under 4 years of age before taking 
theoretical and practical test in relation to Early Childhood Education. This course will equip the teachers before service and teachers with this certificate is eligible to be a certified educator in the nursery in Malaysia. The details of informants' information are showed in the Table 1.

Table 1. Informants Background Information

\begin{tabular}{clcc}
\hline Code & Position & $\begin{array}{c}\text { Academic } \\
\text { Qualification }\end{array}$ & $\begin{array}{c}\text { Year } \\
\text { of } \\
\text { service }\end{array}$ \\
\hline O1 & Owner & Masters & $\begin{array}{c}15 \\
\text { years }\end{array}$ \\
\hline S1 & Supervisor & Bachelor & 6 years \\
\hline P1 & Teacher 1 & Diploma & 5 years \\
\hline P2 & Teacher 2 & Diploma & 5 years \\
\hline P3 & Teacher 3 & $\begin{array}{c}\text { PERMATA } \\
\text { Certification }\end{array}$ & 5 years \\
\hline P4 & Teacher 4 & $\begin{array}{c}\text { PERMATA } \\
\text { Certification }\end{array}$ & 5 years \\
\hline
\end{tabular}

\section{FINDINGS AND DISCUSSION}

The discussion from the responses given by the informants involved in the FGD session were grouped into several themes. The themes underlined in the discussion include the competencies of teachers, cooperation from parents, time constraints and records management. The findings of the study will be discussed in accordance to the themes.

\section{Educator Competence}

All informants selected in the study are qualified to be the academic staffs in the nursery. All informants are certified and own a PERMATA Early Childhood Care and Education certificate. This is due to the requirements of passing the PERMATA Early Childhood Care and Education Course. This aspect is in-line with the legal provisions of the Orphanages Act 1984 (Amendment 2007) and the Childcare Centers Regulations 2012, which states that:

14. (2). A registered educator/caregiver must be a person who :

a) is a citizen of Malaysia

b) aged eighteen years and above c) has passed the PERMATA Early Childhood Care and Education course

d) is registered as a registered educator/caregiver of children under Rule 16

(Permata Division, Prime Minister Office, 2013 pg 487)

Limited knowledge and skills in the field of early childhood education among nursery educators are an issue in implementing assessment of child development. This is because to assess, the educator must understand the concept of child development, fathom the milestones of children, and master the appropriate and significant practice to correspond to the development. This is to ensure the assessment process is executed accordingly and the findings are reliable. The findings revealed that educators in nurseries are not competent to conduct assessments due to limitations in this area and lack of professional training leading to this aspect.

"To assess these children, you need many advanced skills. The teacher needs to understand the concepts of development, milestones, and what follow-up actions should be given to them. SPM graduates can also be nursery teachers just by taking a three-month PERMATA course. It gets worse when there is insufficient training provided to the teacher. That is why it is challenging to find teachers who are capable to conduct the assessment..."(O1)

In addition, teachers with long-term service are seen to have advance skills than new teachers. Despite having the same level of qualifications, experienced educators are said to be better in handling the assessments compared to the inexperienced teachers. In addition, it is also revealed that experienced teachers are more capable in making observation and are more sensitive to changes reflected from a child. 


\section{Cooperation from parents}

The informants acknowledged that parental involvement is also pertinent to gather reliable and authentic data. It is mentioned that teachers are able to conduct observations and assessments while the children are physically at the nursery but parents also need to observe and track their children's development at home. Involvement by both parties would also ensure the validity and reliability of the data gained.

Lack of cooperation by the parents is said to be one of the issues and challenges faced in conducting the children's assessment. The parents are provided with Child Development Log Book and Developmental Checklist given by the teachers so the assessments could be continued at home. However, it is revealed that poor participation and support by the parents have resulted in lack of comprehensive data obtained. According to informant P2, the form is either emptied or incomplete. This results in the dependency of the teachers to execute all of the observations and assessments when it should be conducted by both parties. It serves as a struggle for the teachers to enhance the reliability of the assessment which later lead to difficulties in devising a collective decision regarding the follow-up action to the child.

"I have given the observation forms for parents to monitor their children at home, but only some participated in it. Some of them just merely tick the form without providing any remarks for us (teachers). Some parents submit incomplete forms and we had to tick the forms ourselves..."(P2)

According to S1, parents do not recognize the importance this assessment. Some parents treat the nurseries as merely a place to put their child in while they are fulfilling their commitments at work while others assume that teachers in the nursery only needs to 'babysit' their children. It reveals that the parents are not aware that the teachers are not only 'babysitting' but to also plan learning activities, educate and conduct assessments for their children. This misunderstanding should be intervened as it is important for the child's potential to be identified as early as possible so that it can be further developed. In this regard, S1 has also stressed that necessary actions must be taken to correct these misunderstandings as well as to enhance the public awareness upon the collaborative assessments.

In addition, the $\mathrm{O} 1$ informant has also addressed the importance of integrating Information and Communication Technology (ICT) in the assessment. It is also highlighted that there is a need to develop a mobile system or application to be used by both teachers and parents during the assessments. This will ease the process for both parties to observe, assess and record the data.

\section{Time constraints}

It is pertinent to note that the assessment conducted in the nursery is different compared to the assessment in formal education. Assessment of children is carried out through series of observational methods for data collection, which needs to be recorded, interpreted, and reported. This process requires meticulousness and a long period of time for it to be regulated. Findings of the study showed that teachers face time constraints to perform the assessment for the child respectively. This adds up to the preexisting routines and tasks that need to be completed. Despite being aware of the importance of the assessment, it is mentioned that they are provided limited time as they are overwhelmed with other tasks including preparing the children, food and drinks as well as cleaning.

"At the nursery, we already have a packed work schedule. In the morning, we clean the nursery, prepare the breakfast, greet the children, bathe and take care of them, 
including nursing them. In the afternoon, we proceed to prepare lunch, then it is time for them to take naps. When they get up, we need to prepare afternoon tea, take them to the park. I don't have time to assess even one child at a time..."(P3)

\section{Records Management}

Managing the children's developmental records is also a challenge for the teachers. According to P4 informant, teachers face problems in managing and updating children's developmental records. All documents related to the child's development should be recorded and kept up to date. This is important to monitor the child's development from time to time.

"For records management, we use a filing system. All of our children's work is included in their files separately. It's challenging to constantly update it. You have to open and arrange them one by one. During Open Day these are the documents we need to report to the parents individually..."(P4)

In addition, $\mathrm{P} 4$ informant also expressed the need to integrate ICT for the record-keeping process as a tool that would assist the process. Consequently, the integration like Google Drive, a tablet or computer could reduce the use of storage space, management cost while providing a better data security.

The issues and challenges as well as suggestions for improvement obtained from this study are summarized in Table 2 below:
Table 2: Issues, challenges and proposed solutions to improve children's assessment in nursery

\begin{tabular}{ll}
\hline \multicolumn{1}{c}{$\begin{array}{c}\text { Issues and } \\
\text { Challenges }\end{array}$} & Proposed solutions \\
\hline $\begin{array}{l}\text { Teacher's } \\
\text { Competency }\end{array}$ & $\begin{array}{l}\text { Continuous } \\
\text { professional } \\
\text { development }\end{array}$ \\
& $\begin{array}{l}\text { A comprehensive } \\
\text { module to } \\
\text { implement the } \\
\text { assessment }\end{array}$ \\
\hline $\begin{array}{l}\text { Parental } \\
\text { Involvement }\end{array}$ & $\begin{array}{l}\text { Mobile application } \\
\text { for collaborative } \\
\text { and } \quad \text { collective } \\
\text { assessment }\end{array}$ \\
& $\begin{array}{l}\text { Creating awareness } \\
\text { within the society }\end{array}$ \\
\hline Time constraints & $\begin{array}{l}\text { Hiring teacher } \\
\text { assistant to assist } \\
\text { the routine tasks }\end{array}$ \\
\hline $\begin{array}{l}\text { Integration of ICT } \\
\text { managemet }\end{array}$ & $\begin{array}{l}\text { Inclusion of devices } \\
\text { or electronic tools } \\
\text { like a tablet or } \\
\text { computer to keep } \\
\text { the record }\end{array}$ \\
&
\end{tabular}

As an educator, carrying out and implementing a child's assessment is a responsibility that needs to be fulfilled. Developmental assessment is an important component in the early childhood education because it provides data like strengths, weaknesses, and potentials which will later allow the teachers to identify and develop the aspect to reach its optimal level (Bredekamp, 2017; McAfee, Leong \& Bodrova, 2016 and Beaty, 2010). The issue of educators' competencies and qualifications is not new as it has been discussed in many in previous studies. It is revealed that educators with qualifications and experience will perform learning and assessment activities better. This is supported by a study conducted by Norsyafinaz and Faridah (2018), who 
stated that experienced teachers tend to conduct teaching and learning including pre-numeration assessment better.

Parental involvement in the assessment is also seen as a struggle. This is due to the fact that parents do not realize the importance of the assessment and the underlying reasons for their involvement. Therefore, it is proposed that an on-going advocacy effort should be strengthened to enhance the awareness to the general public. This is in accordance to Anane and Anhwere (2013), who urged the spread of awareness to the related parties of the significance of the assessment.

From the suggested improvement mentioned above, it is also important to note that the use of ICT has a strong influence among nursery educators. Therefore, it is proposed to conduct a study on developing a nursery child assessment management model or developing a mobile application for child assessment. This study could use the ADDIE Model, which includes analysis (analyze), design, development, implementation and evaluation process. Thus, a model, system or mobile application will be more comprehensive and relevant for use in the assessment of child development.

\section{CONCLUSION}

In conclusion, this study has provided an overview of the issues and challenges as well as suggestions for improvement in the assessment of child development specifically in the nursery. Assessment of children should be carried out with the right procedures to ensure that the strengths and weaknesses of children could be acknowledge and subsequently could be optimized to a better level. Therefore, stakeholders should understand the issues and challenges educators face in this regard and the need to address the issue promptly.

\section{REFERENCES}

Akta Pendidikan 1996.

Anane, E., \& Anhwere, Y., M., (2013). Assessment in Preschools in Ghana: Issues and Challenges. Journal of Education and Practice 4 (22): 24-30

Permata, B (2013). Modul Pendidik. Kursus Asuhan dan Didikan Awal Kanak-Kanak Permata Negara. Serdang: Penerbit UPM.

Beaty, J. J. (2009). Observing Development of the Young Child. New York: Pearson.

Bredekamp, S. (2017). Effective Practices in Early Childhood Education. Building

Foundation. New York: Pearson

McAfee, O., Leong, D., J., \& Bodrova, E., (2016). Assessing and Guiding Young Children's Development and Learning. New York: Pearson

Merriam, S. B. (2009). Qualitative Research. A Guide to Design and Implementation. San Francisco: Jossey Bass

Norsyafinaz, A. S. \& Faridah, Y. (2018). Amalan Perancangan, Pelaksanaan dan Pentaksiran dalam Proses Pengajaran dan Pembelajaran Pranumerasi di Tadika Swasta. Jurnal Pendidikan Malaysia 43(2). 101-110

Nur, I. Z., et all. (2016). The Assessment of Children's Performance at Child Care Centre. Procedia Social and Behavioral Sciences 234. 64-73

Nyumba, T.O., Wilson, K., Derrick, C. J., \& Mukherjee, N., (2018). The use of focus group discussion methodology: Insights from two decades of application in conservation. Retrieved from https://besjournals.onlinelibrary. wiley.com/doi/full/10.1111/20412 $\underline{0 X .12860}$ 